\title{
Energy balance in cystic fibrosis when stable and during a respiratory exacerbation
}

Citation for published version (APA):

McCloskey, M., Redmond, A. O., McCabe, C., Pyper, S., Westerterp, K. R., \& Elborn, S. J. (2004). Energy balance in cystic fibrosis when stable and during a respiratory exacerbation. Clinical Nutrition, 23(6), 1405-1412. https://doi.org/10.1016/j.clnu.2004.06.010

Document status and date:

Published: 01/01/2004

DOI:

10.1016/j.clnu.2004.06.010

Document Version:

Publisher's PDF, also known as Version of record

Document license:

Taverne

Please check the document version of this publication:

- A submitted manuscript is the version of the article upon submission and before peer-review. There can be important differences between the submitted version and the official published version of record.

People interested in the research are advised to contact the author for the final version of the publication, or visit the DOI to the publisher's website.

- The final author version and the galley proof are versions of the publication after peer review.

- The final published version features the final layout of the paper including the volume, issue and page numbers.

Link to publication

\footnotetext{
General rights rights.

- You may freely distribute the URL identifying the publication in the public portal. please follow below link for the End User Agreement:

www.umlib.nl/taverne-license

Take down policy

If you believe that this document breaches copyright please contact us at:

repository@maastrichtuniversity.nl

providing details and we will investigate your claim.
}

Copyright and moral rights for the publications made accessible in the public portal are retained by the authors and/or other copyright owners and it is a condition of accessing publications that users recognise and abide by the legal requirements associated with these

- Users may download and print one copy of any publication from the public portal for the purpose of private study or research.

- You may not further distribute the material or use it for any profit-making activity or commercial gain

If the publication is distributed under the terms of Article $25 \mathrm{fa}$ of the Dutch Copyright Act, indicated by the "Taverne" license above, 


\title{
Energy balance in cystic fibrosis when stable and during a respiratory exacerbation
}

\author{
Margaret Mc Closkey ${ }^{a, *}$, Aileen O.B. Redmond ${ }^{a}$, Christine Mc Cabe ${ }^{a}$, \\ Siobhan Pyper ${ }^{a}$, Klass R. Westerterp ${ }^{b}$, Stuart J. Elborn ${ }^{a}$
}

\author{
${ }^{a}$ Adult and Paediatric Cystic Fibrosis Units, Belfast City Hospital and Royal Belfast Hospital for Sick \\ Children, Belfast, Northern Ireland, UK \\ ${ }^{\mathrm{b}}$ Department of Human Biology, University of Maastricht, Holland
}

Received 17 February 2003; accepted 12 June 2004

\section{KEYWORDS \\ Energy intake; \\ Energy expenditure}

\begin{abstract}
Summary Background \& aims: Undernutrition is common in young adult patients with cystic fibrosis (CF) and implies an imbalance between energy intake and total energy expenditure (TEE). The aim of this study was to measure energy intake and TEE expenditure in a group of patients when they were clinically stable at home and during an exacerbation of respiratory symptoms when they were in hospital receiving intravenous antibiotics.

Methods: Eleven patients aged between 15 and 40 years with moderate respiratory disease, mean $\mathrm{FEV}_{1} 51.4 \%$ predicted took part. An exacerbation was defined as $>15 \%$ decrease in $\mathrm{FEV}_{1}$, an increase in sputum production and a decision to treat in hospital with intravenous antibiotics. Resting energy expenditure (REE) was measured using indirect calorimetry and energy intake by 3 day food diaries. TEE expenditure was measured using $24 \mathrm{~h}$ heart rate and doubly isotopically labelled water.

Results: REE was higher at the beginning of an exacerbation than the end, $P<0.05$. There was no significant difference in TEE during the stable period compared to the exacerbation $10.53(2.39) \mathrm{MJ} /$ day compared to $8.77(1.59) \mathrm{MJ} /$ day using doubly isotopically labelled water. There was no difference in energy intake during the exacerbation compared to the stable period, $11.19(2.31) \mathrm{MJ} /$ day compared to11.77(2.30) $\mathrm{MJ} /$ day.

Conclusions: There was no difference in TEE and energy intake when patients were unwell in hospital compared to when they were stable at home despite an increase in REE.

(C) 2004 Elsevier Ltd. All rights reserved.
\end{abstract}

*Corresponding author. Tel.: +44-28-90329241x3119; fax: +44-28-90263546

E-mail address: mccloskeymargaret@hotmail.com (M. Mc Closkey). 


\section{Introduction}

Reduced body weight is a common problem within the cystic fibrosis (CF) population and is an adverse prognostic indicator. ${ }^{1-4}$ This is due to a disturbance of energy balance resulting from either decreased energy intake (EI), increased total energy expenditure (TEE) or a combination of both. ${ }^{5}$ The contribution of either decreased El or increased TEE has not been fully assessed in the CF population.

Many studies assessing energy balance in other chronic diseases including lung carcinoma and Crohn's disease have used resting energy expenditure (REE) as an estimate of TEE. However an increase in REE, which accounts for about $80 \%$ of TEE, which has been demonstrated in these conditions does not necessarily imply an increase in TEE therefore the energy balance equation is incomplete. ${ }^{6,7}$ There has however been a recent study assessing the full energy balance equation in patients with human immunodeficency virus (HIV) infection, this study found that weight loss in patients with HIV infection was due to a decrease in $\mathrm{EI}$ and that TEE remained unchanged or decreased despite an increase in REE. ${ }^{8}$

Some studies have noted an increase in REE in patients with CF associated with a respiratory exacerbation which subsequently reduces significantly after a course of intravenous antibiotics. ${ }^{9}$ This increase in REE has been associated with a change in intermediary metabolism, such as an increase in catecholamine levels, increased lipolysis and increased proteolysis. Some of these effects have been shown to be mediated by pro-inflammatory cytokines particularly tumour necrosis factor alpha (TNF $\alpha){ }^{10}$ TNF $\alpha$ has also been shown to have an anorectic effect resulting in a decreased energy intake. ${ }^{11}$

The aim of the present study was to assess the full energy balance equation in patients with CF by measuring El, REE and TEE in adolescent and adult patients with CF when they were stable and during the treatment of an exacerbation of respiratory symptoms.

\section{Materials and methods}

Eleven patients with CF mean age 23 years (range 15-40 years ) and moderately severe respiratory disease, $\mathrm{FEV}_{1}$ 30-70\% predicted were recruited. Patients were studied when they were clinically stable and during an exacerbation of respiratory symptoms. A respiratory exacerbation was determined as more than $15 \%$ decrease in $\mathrm{FEV}_{1}$ from an individual's usual level, an increase in sputum production, patient perception of a worsening of symptoms and a physician decision to treat with 2 weeks of intravenous antibiotics.

Each study period was 2 weeks. When the patients had an exacerbation of symptoms they were in hospital for at least the first 10 days of treatment. The only difference in medication between the two study periods was the intravenous antibiotic therapy during the exacerbation. All patients were chronically colonised with Pseudomonas aeruginosa ( $P$. aeruginosa) and some were colonised with Burkholderia cepacia (B. cepacia) in addition to the $P$. aeruginosa.

\section{Measurement of resting energy expenditure}

Subjects attended the study room between 8.00 and $9.30 \mathrm{am}$, having fasted from $10.00 \mathrm{pm}$ the previous night. Subjects were driven straight to the study room from their own home or from hospital. Patients had omitted their usual am medication on the morning of the study. All subjects rested on the bed in the study room which was inclined at $45^{\circ}$ to the horizontal for a period of twenty minutes to acclimatise. They then had gas exchange measurements taken for $20 \mathrm{~min}$ at $15 \mathrm{~s}$ intervals. A face mask was used to collect expired air as previous studies had shown no difference in REE measurements using a face mask or a mouth piece. ${ }^{12}$ Coughing did not prove to be a problem during the measurements. All subjects attended the study room on day one and between day 12 and day 14 to have REE measured. They all had been familiarised with the equipment on a previous visit before any of the studies commenced. REE was calculated from $\mathrm{O}_{2}$ consumption and $\mathrm{CO}_{2}$ production using the modified Weir equation. ${ }^{13}$

\section{Measurement of total energy expenditure}

TEE was assessed using doubly isotopically labelled water (DLW) and $24 \mathrm{~h}$ heart rate (24h HR) methodology.

Doubly isotopically labelled water: DLW is the gold standard field technique for the measurement of TEE, the main limiting factor in its use is the cost of the isotopes. The technique is based on the principle that ${ }^{2} \mathrm{H}$ labels the body water pool and $\mathrm{O}^{18}$ labels both the water and bicarbonate pools so that $\mathrm{CO}_{2}$ production can be estimated from the difference in elimination of the two isotopes. ${ }^{14-16}$ In these studies the Masstricht protocol for measurement of EE using DLW wa s followed. ${ }^{17}$ This involves a six point protocol allowing comparison of TEE 
within the first and second week of a fourteen day observation period comparison of TEE within the first and second week of a fourteen day observation period to check for sampling errors. The protocol in these studies was as follows:

1 Patients were weighed before entering the study and body water was estimated from age, sex and weight specific formulae. ${ }^{18}$

2 Weighted isotope doses were ordered from the University of Limburg, Masstricht according to estimated body water of the subjects.

3 On day zero of the study period subjects passed a pre-dose urine sample at $9 \mathrm{pm}$, they then drank the weighted dose of isotope, which contained $0.05 \mathrm{~g} / \mathrm{kg}$ body water of ${ }^{2} \mathrm{H}_{2} \mathrm{O}$ and $0.1 \mathrm{~g} / \mathrm{kg}$ body water of $\mathrm{H}_{2} \mathrm{O}^{18}$, the volume of water being between 80 and $120 \mathrm{ml}$. Subjects drank the water straight from the bottle and then rinsed the bottle with $50 \mathrm{mls}$ of tap water and drank this also, this was to ensure all the isotopes were consumed.

4 The next morning (day 1) patients collected a sample from their second voiding and then collected a second sample on the evening of day 1 , noting the time at which the sample was collected.

5 Samples were then collected on day 8 morning and evening and day 15 morning and evening.

Body composition was measured from the morning voiding of day 1 after a $10 \mathrm{~h}$ equilibration period. Samples were frozen at $-20^{\circ} \mathrm{C}$ until transfer to Masstricht for analysis.

Twenty-four hour heart rate methodology: The physiological basis of this method is related to the fact that heart rate (HR) increases with oxygen consumption in a linear fashion during physical activity. ${ }^{19-22}$ Patients were studied in the morning 10 min after having REE measured. Patients underwent calibration on day 1 and day 12 of the 2 week study period. Patients sat for $6 \mathrm{~min}$, stood for $6 \mathrm{~min}$, walked on a treadmill for $6 \mathrm{~min}$ at a speed of $2.7 \mathrm{~km} /$ hour and gradient of $5 \%$ and if able at a speed of $4.0 \mathrm{~km} /$ hour and a gradient of $10 \%$ for $6 \mathrm{~min}$. Patients who were in hospital were generally unable to perform the second stage of this exercise program, therefore a modified program was used: 6 minutes at a speed of $2 \mathrm{~km} / \mathrm{hr}$ and 0 gradient, and 6 minutes at a speed of $2.7 \mathrm{~km} / \mathrm{h}$ and 0 gradient. A preliminary $3 \mathrm{~min}$ equilibration period was allowed at each stage followed by a 3 min sampling period. The calibration point for each activity was taken as the mean of the 3 min sampling period for $\mathrm{HR}$ and $\mathrm{VO}_{2}$. Expired gas was collected via a face mask(Hans Rudolph Inc, Kansas City) to the Quinton equipment. An individual heart rate $/ \mathrm{O}_{2}$ consumption graph was drawn manually after each calibration.

Patients then put on a heart rate monitor (Polar Sports Tester, Kempele, Finland) and wore this until going to bed the same night, monitors were removed at night as sleep energy expenditure was estimated as REE.

Fat free mass (FFM) was calculated from the first early morning sample as previously described. ${ }^{17}$ TEE was calculated from 24 hour HR methodology by assessing FLEX heart rate, which is the mean of the highest resting heart rate and lowest heart rate during exercise during the calibration procedures and drawing individual $\mathrm{HR} / \mathrm{O}_{2}$ consumption curves as described previously. ${ }^{20,21}$ TEE by the DLW method was calculated from the different elimination rates of deuterium and oxygen 18 as described. ${ }^{15,17}$

\section{Assessment of dietary intake}

Dietary intake was assessed by 3 day food diaries recorded on day one to three of each study period. ${ }^{23-26}$ Each patient collaborated with a dietitian specialising in CF. Dietary records were converted to El by COMPEAT (version four).

\section{Statistical analysis}

Comparison of data when patients are stable and during an exacerbation was by paired $t$-tests. Correlation between variables was by linear regression. Comparison between $24 \mathrm{~h}$ HR and DLW methodology was assessed by the method of Bland and Altman. ${ }^{27}$ TEE measurements and EI measurements were expressed in $\mathrm{MJ} /$ day.

\section{Ethical approval}

This study was approved by the ethical committee of Queens University of Belfast and all subjects gave written informed consent to participating in the study.

\section{Results}

Six female and five male patients with CF took part in this study over an 18 month period. All patients participated in both parts of the study, completing 2 weeks of energy balance measurements when they were stable and when they were in hospital receiving intravenous antibiotic therapy. Four patients completed the exacerbation part of the 
study first, seven completed the stable part of the study first. There was at least three months between the two study periods, the longest interval was seven months, mean interval was 4.2(1.2) months. DLW data were incomplete in 3 patients. Patient numbers 2 and 7 did not take DLW during a respiratory exacerbation as supplies were not available at the time they became acutely unwell. Patient number 6 broke the bottle of DLW during the exacerbation but did not reveal this until he had completed the study. Six patients were colonised with $P$. aeruginosa alone and five patients were colonised with $B$. cepacia and $P$. aeruginosa. All patients received 2 weeks of intravenous antipseudomonal antibiotics during the exacerbation period. Those patients who were colonised with $B$. cepacia were treated with antibiotics with in vitro sensitivities to the organism, no patients in the study were colonised with multi-resistant $B$. cepacia on in vitro testing at the time of participating in the study.

The mean weight of patients during the stable period was $50.2(9.6) \mathrm{kg}$ and $49.9(10.1) \mathrm{kg}$ at the beginning of the exacerbation period, this difference was not significant. At the end of the exacerbation mean weight was $50.4(10.3) \mathrm{kg}$. Six patients increased their body weight during the exacerbation and four maintained their body weight, one patient lost weight during the exacerbation. Mean $\mathrm{FEV}_{1}$ during the stable period was $51(11) \%$ predicted. This was significantly higher than at the beginning of the exacerbation period $37(9) \%$ predicted $(P<0.05)$. By the end of the 2 weeks of intravenous antibiotics $\mathrm{FEV}_{1}$ was similar to during the period of clinical stability $49(11) \%$ predicted (Table 1).

REE was higher at the beginning of an exacerbation compared to the end $8.3(0.9) \mathrm{MJ} /$ day compared to 7.1(1.2) MJ/day, $(P<0.05)$ at the end of the intravenous antibiotics. There was no difference between REE during the stable period $7.3(0.9) \mathrm{MJ} /$ day and the end of the exacerbation.

There was no significant difference between TEE during the period of clinical stability and during the exacerbation, however there was a trend for TEE to be lower during the exacerbation period compared to the stable period using either $24 \mathrm{~h} \mathrm{HR}$ or DLW methodologies (Table 2). TEE measurements by DLW and $24 \mathrm{~h} \mathrm{HR}$ methodologies during the stable period and during the exacerbation were similar, the mean difference between the two methods being $14(11) \%$ in patients when they were stable and $13(18) \%$ during the exacerbation. There was no correlation between TEE and FFM or FEV 1 .

Resting heart rate was significantly higher at the start of an exacerbation 85 (5) beats per min and decreased by the end of the exacerbation 81 (6) beats/min $(P<0.05)$.

During the period of clinical stability heart rate was 79 (7) beats/min. FLEX heart rate was higher but not significantly so at the beginning of an exacerbation 103 (8) beats/min compared to the end 101 (7) beats/min. FLEX heart rate also tended to be higher at the end of the exacerbation compared to the period of clinical stability 99 (7) beats/min, this was not statistically significant.

Physical activity levels (PAL) were significantly higher when patients were stable $1.3(0.1) \mathrm{com}$ pared to the beginning of an exacerbation 1.1(0.004), $P=0.001$. There was no significant difference in PAL at the beginning of an exacerbation compared to the end 1.2(0.2) (Table 3).

There was no significant difference between $\mathrm{El}$ during the period of clinical stability, $11.2(2.3) \mathrm{MJ} /$ day and during the exacerbation, 11.8 (2.3) MJ/day (Table 4). When patients were divided into those who increased in weight during the treatment of an exacerbation and those who remained the same weight or lost weight there was a difference between TEE and El during the two periods. Those patients who increased weight had an increase in their El during the exacerbation. There was good correlation between TEE and El during the stable period using $24 \mathrm{~h}$ HR methodology, $r^{2}=0.6, P=0.03$. Correlation between TEE and El using DLW methodology was $r^{2}=0.6, P=0.08$ which is not significant. There was no correlation between TEE and EI during the exacerbation periods using both methodologies. There was no correlation between $\mathrm{El}$ and FFM.

\section{Discussion}

This study indicates that during an exacerbation of respiratory symptoms in patients with moderately severe CF, TEE is not increased despite an increase in REE compared to a period of clinical stability. This study found a similar pattern to other published studies measuring REE during an exacerbation of respiratory symptoms, that is that REE is increased at the beginning of an exacerbation and decreases to levels seen when patients are stable by the end of 2 weeks of intravenous antibiotics. 9,28 Despite this increase in REE there is not a corresponding increase in TEE. Physical activity levels were decreased at the beginning of treatment of an exacerbation compared to when patients were stable.

This is similar to published data in patients with HIV infection. A recent study using DLW demon- 


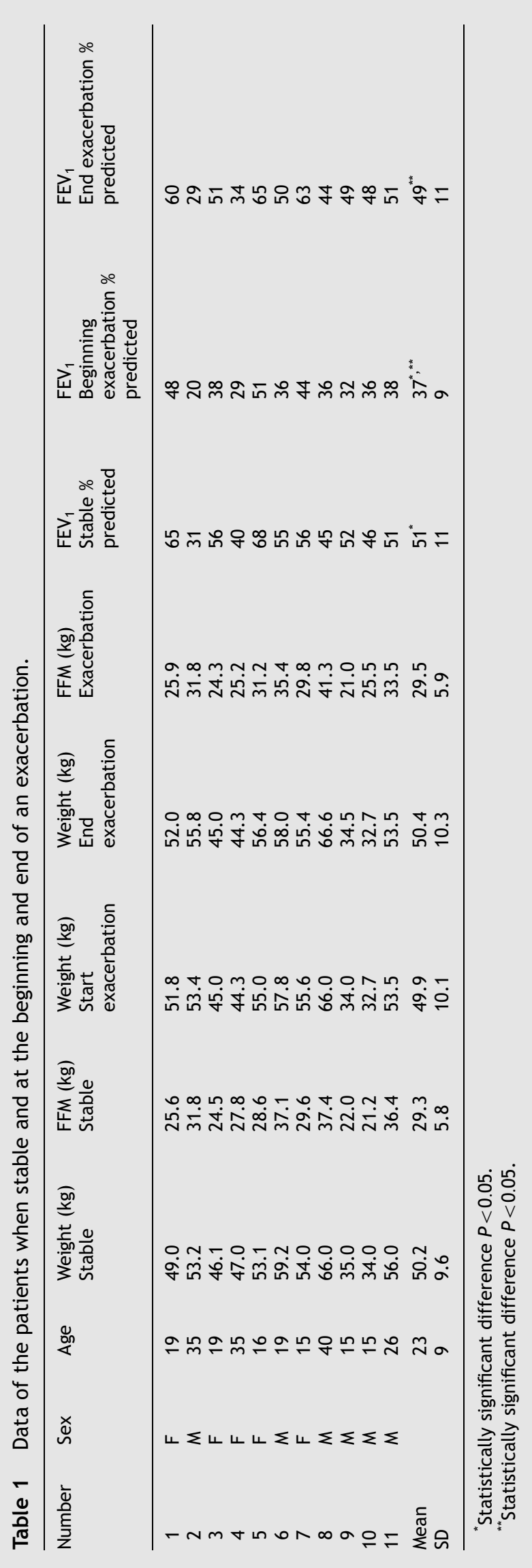

strated an increase in REE in these patients but TEE was similar to control populations. ${ }^{8}$ A number of similar studies in patients with chronic obstructive pulmonary disease (COPD) have given conflicting results. Baarends et al. demonstrated no difference in TEE in patients with COPD who had an increase in REE and those who had a normal REE. ${ }^{29}$ Interestingly Baarends, in a further study demonstrated that TEE was increased in patients with COPD relative to a control population whereas Hugli found no difference in TEE in patients and controls. ${ }^{30,31}$ The patients in Baarends study were undergoing a pulmonary rehabilitation program so differing physical activity levels between the study groups could explain the conflicting results as well as differing techniques as Hugli used a $24 \mathrm{~h}$ calorimeter in his study.

All of the patients in this study had moderately severe lung disease, mean $\mathrm{FEV}_{1} 54 \%$ predicted and the data on TEE in this sub population cannot be extrapolated to those more severely ill patients with an $\mathrm{FEV}_{1}<30 \%$ predicted or indeed those patients who are mildly affected with an $\mathrm{FEV}_{1}>70 \%$ predicted as it is possible that deteriorating pulmonary function is associated with a more marked restriction on physical activity which may result in different TEE measurements.

We have previously assessed the repeatability and reproducibility of $24 \mathrm{~h}$ HR methodology in patients with CF compared to the DLW method and found the technique to have good group repeatibility and reproducibility. ${ }^{32}$ We also found that $24 \mathrm{~h}$ HR consistently underestimated TEE in patients and in a control group compared to DLW, other workers have noted this as well within normal populations. ${ }^{14,16,32}$ The results of this study are in keeping with these previous findings and demonstrate that the $24 \mathrm{~h}$ HR technique is valid for measuring TEE in patients during an exacerbation of respiratory symptoms as well as when they are stable.

Body weight increased in those patients who increased their El whilst in hospital. Those patients who did not increase their El did not have a corresponding increase in body weight and because TEE did not alter in the patients it is the change in El which resulted in the increase in weight.

The authors are aware that the numbers recruited in the present study were small which limits the degree to which the data can be interpreted and this is a valid criticism of the study. There are two main reasons for the small numbers, the major one being that the study was very intensive and time consuming for the patients. It involved a huge amount of cooperation on their part. Fourteen patients completed both parts of 
Table 2 Total energy expenditure in patients when they are stable and during an exacerbation of respiratory symptoms using $24 \mathrm{~h} \mathrm{HR}$ and DLW methods.

\begin{tabular}{|c|c|c|c|c|c|}
\hline \multirow[b]{2}{*}{ Number } & \multicolumn{3}{|c|}{ HR method } & \multicolumn{2}{|c|}{ DLW method } \\
\hline & $\begin{array}{l}\text { TEE stable } \\
\text { (MJ/day) }\end{array}$ & $\begin{array}{l}\text { TEE beginning } \\
\text { (MJ/day) }\end{array}$ & $\begin{array}{l}\text { TEE end } \\
\text { (MJ/day) }\end{array}$ & $\begin{array}{l}\text { TEE stable } \\
\text { (MJ/day) }\end{array}$ & $\begin{array}{l}\text { TEE exacerbation } \\
\text { (MJ/day) }\end{array}$ \\
\hline 1 & 8.7 & 7.5 & 7.4 & 12.0 & 10.2 \\
\hline 2 & 10.4 & 9.5 & 9.0 & 10.3 & N/A \\
\hline 3 & 8.5 & 8.6 & 7.1 & 8.0 & 7.1 \\
\hline 4 & 7.7 & 7.9 & 9.0 & 8.6 & 9.3 \\
\hline 5 & 10.0 & 7.3 & 7.8 & 11.1 & 7.7 \\
\hline 6 & 10.5 & 10.3 & 10.7 & $\mathrm{~N} / \mathrm{A}$ & 12.1 \\
\hline 7 & 7.6 & 8.3 & 9.4 & 9.2 & $\mathrm{~N} / \mathrm{A}$ \\
\hline 8 & 10.3 & 11.7 & 10.9 & 13.4 & 8.5 \\
\hline 9 & 8.2 & 7.6 & 6.6 & 9.3 & 7.3 \\
\hline 10 & 6.1 & 6.5 & 5.3 & 8.2 & 8.0 \\
\hline 11 & 11.7 & 9.2 & 8.9 & 15.2 & 8.8 \\
\hline Mean & 9.1 & 8.6 & 8.4 & 10.5 & 8.8 \\
\hline SD & 1.7 & 1.5 & 1.7 & 2.4 & 1.6 \\
\hline
\end{tabular}

Table 3 Physical acticity levels in patients when stable and during an exacerbation.

\begin{tabular}{llll}
\hline Number & Stable & $\begin{array}{l}\text { Beginning of } \\
\text { exacerbation }\end{array}$ & $\begin{array}{l}\text { End of } \\
\text { exacerbation }\end{array}$ \\
\hline 1 & 1.2 & 1.1 & 1.1 \\
2 & 1.4 & 1.1 & 1.1 \\
3 & 1.2 & 1.1 & 1.2 \\
4 & 1.5 & 1.2 & 1.6 \\
5 & 1.3 & 1.1 & 1.1 \\
6 & 1.5 & 1.2 & 1.5 \\
7 & 1.2 & 1.1 & 1.3 \\
8 & 1.1 & 1.2 & 1.2 \\
9 & 1.4 & 1.1 & 1.1 \\
10 & 1.2 & 1.1 & 1.1 \\
11 & 1.5 & 1.1 & 1.1 \\
Mean & $1.3^{*}$ & $1.1^{*}$ & 1.2 \\
SD & 0.1 & 0.004 & 0.2 \\
\hline
\end{tabular}

"Statistically significant difference $P<0.001$.

the study but three had to be excluded from the analysis because when the principal investigator tried to collect various samples or pieces of equipment the data was unreadable or false. Five patients completed the first half of the study but refused to complete the second 2-week study period. This reflects the huge amount of work those who did participate actually performed and the authors feel confident that despite the small numbers, the data is very accurate as the nature of the study selected out patients who were very diligent and precise in their habits. The second reason for the small numbers was the high financial cost in the purchasing and analysing of the DLW.
A recent study by Bines et al. found that REE and TEE in newborn infants with CF is not different from a control population but it is possible that this pattern of energy expenditure changes as infants grow. ${ }^{33}$ The study by Naon et al. assessed changes in REE and $\mathrm{El}$ in prepubertal children during a respiratory exacerbation and found the increase in REE during an exacerbation to be higher than the increase in El concluding that an increase in energy expenditure was the cause of weight loss and not decreased El. ${ }^{34}$ An increase in $\mathrm{El}$ in prepubertal children during a respiratory exacerbation has been reported but energy expenditure was not measured at the time. ${ }^{35} \mathrm{~A}$ decrease in El in patients with CF when they are unwell has been reported but this did not occur in our population group. It is possible that in our patient group there was a decrease in El the few days prior to hospital admission when they were unwell at home and when they were actually admitted to hospital and commenced treatment and were seen by a CF dietitian who was strongly encouraging food intake, the usual anorexia was overcome. This suggests that in hospital treatment of infective exacerbations of symptoms in adolescent and adult patients with CF may be beneficial nutritionally by maintaining El. Patients were strongly encouraged to eat when in hospital and it would be informative to measure $\mathrm{El}$ in young adolescent and adult patients similar to this group when treated for a respiratory exacerbation with "at home" antibiotics.

The lack of correlation between El and TEE during the exacerbation may be related to these external influences on eating pattern and it would 
Table 4 Energy balance according to change in weight during the exacerbation period.

\begin{tabular}{|c|c|c|c|c|c|c|c|c|}
\hline \multirow[b]{2}{*}{ Patient } & \multirow[b]{2}{*}{ Weight change $(\mathrm{kg})$} & \multicolumn{3}{|c|}{ Stable } & \multicolumn{4}{|c|}{ Exacerbation } \\
\hline & & $\begin{array}{l}\text { TEE } \\
\text { DLW (MJ) }\end{array}$ & $\begin{array}{l}\text { TEE } \\
\text { HR (MJ) }\end{array}$ & $\begin{array}{l}\text { El } \\
\text { (MJ) }\end{array}$ & $\begin{array}{l}\text { TEE } \\
\text { DLW (MJ) }\end{array}$ & $\begin{array}{l}\text { TEE start } \\
\text { HR (MJ) }\end{array}$ & $\begin{array}{l}\text { TEE end } \\
\text { HR (MJ) }\end{array}$ & $\begin{array}{l}\mathrm{El} \\
(\mathrm{MJ})\end{array}$ \\
\hline \multicolumn{9}{|c|}{ Patients who had an increase in weight during the exacerbation period } \\
\hline 1 & 0.2 & 12.0 & 8.7 & 10.5 & 10.2 & 7.5 & 7.4 & 14.7 \\
\hline 2 & 2.4 & 10.3 & 10.4 & 12.1 & & 9.5 & 9.0 & 13.0 \\
\hline 5 & 1.4 & 11.1 & 10.0 & 12.7 & 7.7 & 7.7 & 7.8 & 14.0 \\
\hline 6 & 0.2 & & 10.5 & 10.1 & 12.1 & 10.3 & 10.7 & 14.6 \\
\hline 8 & 0.6 & 13.4 & 10.3 & 11.1 & 8.5 & 11.6 & 10.9 & 7.6 \\
\hline 9 & 0.5 & 9.4 & 8.2 & 9.5 & 7.3 & 7.6 & 6.6 & 10.8 \\
\hline Mean & & 11.2 & 9.7 & 11.2 & 9.2 & 9.0 & 8.7 & 12.3 \\
\hline SD & & 1.6 & 9.8 & 1.4 & 2.0 & 1.7 & 1.8 & 2.8 \\
\hline \multicolumn{9}{|c|}{ Patients who did not change weight during the exacerbation period } \\
\hline 3 & 0.0 & 8.0 & 8.5 & 12.4 & 7.1 & 8.6 & 7.1 & 12.8 \\
\hline 4 & 0.0 & 8.6 & 7.7 & 9.5 & 9.3 & 7.9 & 9.0 & 10.3 \\
\hline 7 & -0.2 & 9.2 & 7.6 & 7.2 & & 8.3 & 9.4 & 8.7 \\
\hline 10 & 0.0 & 8.2 & 6.1 & 11.0 & 8.0 & 6.5 & 5.3 & 12.5 \\
\hline 11 & 0.0 & 15.2 & 11.7 & 16.0 & 8.8 & 9.2 & 8.9 & 11.3 \\
\hline Mean & & 9.8 & 8.3 & 11.2 & 8.2 & 8.1 & 7.9 & 11.1 \\
\hline SD & & 3.0 & 2.1 & 3.3 & 1.0 & 1.0 & 1.7 & 1.7 \\
\hline
\end{tabular}

be helpful to know whether when patients are treated at home there is a more direct correlation between El and TEE. Equally important is the issue of $\mathrm{El}$ in patients with more severe respiratory disease as this may not be the same as those patients with moderate disease.

Reilly et al. measured energy balance in children with CF when they were stable and during an exacerbation. ${ }^{36}$ They did not find an increase in REE during an exacerbation although half of the 14 patients in the study had excellent lung function with $\mathrm{FEV}_{1}>80 \%$ predicted. It was also noted that TEE was the same in children when they were stable compared to during an exacerbation although there did seem to be a trend for TEE to be actually decreased during an exacerbation, this is similar to our findings in young adult patients. This may be related to the increased energy required for physical activity in $\mathrm{CF}$ as noted in a recent study. ${ }^{37}$ We had previously shown that TEE in a stable group of patients was not increased relative to a control population despite an increase in REE and this seem to occur because patients had a decrease in physical activity levels. ${ }^{30}$ It is possible that by decreasing physical activity levels even further during an exacerbation an increase in TEE is avoided.

In summary this study shows that in young adult patients with CF with moderately severe respiratory disease TEE is maintained or decreased during an exacerbation of respiratory symptoms despite an increase in REE when they are treated in hospital but $\mathrm{El}$ is maintained.

\section{Acknowledgements}

The authors would like to thank The CF Trust UK for financial assistance to Dr. Mc Closkey and Dr. M.B.E. Livingstone, University of Ulster, Coleraine for her assistance in the use of 24 hour HR monitoring.

\section{References}

1 Dodge JA, Morrison S, Lewis PA, et al. Incidence, population and survival of cystic fibrosis in the UK, 1968-95. Arch Dis Child 1997;77:493-6.

2 Morrison S, Dodge JA, Cole TJ, et al. Height and weight in cystic fibrosis: a cross sectional study. Arch Dis Child 1997;77:497-500.

3 Winklhofer-Roob BM. Nutritional status in cystic fibrosis: where to go from here? Am J Clin Nutr 1998;67:817-8.

4 Bell SC, Bowerman AR, Davies CA, Campbell IA, Shale DJ, Elborn JS. Nutrition in adults with cystic fibrosis. Clin Nutr 1998;17:211-5.

5 Reilly JJ, Edwards CA, Weaver LT. Malnutrition in children with cystic fibrosis: the energy - balance equation. J Pediatr Gastroenterol Nutr 1997;25:127-36.

6 Van den Brekel AJ, Schols AMWJ, Velde GPMT, Buurman WA, Wouters EFM. Analysis of the energy balance in lung cancer patients. Cancer Res 1994;54:6430-3.

7 Zoli G, Katelaris PH, Garrow J, Gasbarrini G, Farthing MJ. Increased energy expenditure in growing adolescents with Crohn's disease. Dig Dis Sci 1996;41:1754-9. 
8 Macallan DC, Noble C, Baldwin C, et al. Energy expenditure and wasting in human immunodeficency virus infection. N Eng J Med 1995;333:83-8.

9 Steinkamp G, Drommer A, Von Der Hardt H. Resting energy expenditure before and after treatment for Pseudomonas aeruginosa infection in patients with cystic fibrosis. Am J Clin Nutr 1993;57:685-9.

10 Elborn JS, Cordon SM, Western PJ, Macdonald I, Shale DJ. Tumour necrosis factor-alpha, resting energy expenditure and cachexia in cystic fibrosis. Clin Sci 1993;85:563-8.

11 Grimble RF. Interaction between nutrients, pro-inflammatory cytokines and inflammation. Clin Sci 1996;91:21-130.

12 Segal KR. Comparison of indirect calorimetric measurements of resting energy expenditure with a ventilated hood, face mask and mouthpiece. Am J clin Nutr 1987;45:1420-3.

13 Weir JBV. New methods for calculating metabolic rate with special reference to protein metabolism. J Physiol 1948;109:1-9.

14 Livingstone MBE, Prentice AM, Coward WA, et al. Simultaneous measurement of free living energy expenditure by the doubly labelled water method and heart-rate monitoring. Am J Clin Nutr 1990;52:59-65.

15 Schoeller DA, Rachette SB. A review of field techniques for the assessment of energy expenditure. $J$ Nutr 1990;120:1492-5.

16 Livingstone MBE, Coward WA, Prentice AM, et al. Daily energy expenditure in free-living children: comparison of heart-rate monitoring with the doubly labelled water method. Am J Clin Nutr 1992;56:343-52.

17 Westerterp KR, Wouters L, Van Marken Lichtenbelt WD. The Maastricht protocol for the measurement of body composition and energy expenditure with labelled water. Obesity Res 1995;3:49-57.

18 Deurenberg P, Westrate JA, Seidell JC. Body mass index as a measure of body fatness: age and sex specific prediction formulas. Br J Nutr 1991;65:105-14.

19 Murgatroyd PR, Shetty PS, Prentice AM. Techniques for the measurement of human energy expenditure: a practical guide. Int J Obesity 1993;17:549-68.

20 Christensen CC, Frey HMM, Foenstelien E, Eng E, Aadland EA, Refsum HE. A critical evaluation of energy expenditure estimates based on individual oxygen consumption/ heart rate curves and average daily heart rate. Am J Clin Nutr 1983;37:468-72.

21 Spurr GB, Prentice AM, Murgatroyd PR, Goldberg GR, Reina $J C$, Christman BS. Energy expenditure from minute by minute heart rate recording: comparison with indirect calorimetry. Am J Clin Nutr 1988;48:552-9.

22 Li R, Deurenberg P, Hautvast JGAJ. A critical evaluation of heart rate monitoring to assess energy expenditure in individuals. Am J Clin Nutr 1993;58:602-7.
23 Black AE, Prentice AM, et al. Measurements of total energy expenditure provide insights into validity of dietary measurements of energy intake. J Am Diet Assoc 1993;93: 572-9.

24 Crawford PB, Obarzanek E, Morrison J, Sabry ZI. Comparative advantage of 3-day food recalls over 24-hour recall and 5-day food frequency validated by observation of 9 and 10 year old girls. J Am Diet Assoc 1994;94:26-630.

25 Kaskoun MC, Johnson RK, Goran MI. Comparison of energy intake by semiquantitative food-frequency questionnaire with total energy expenditure by the doubly labelled water method in young children. Am J Clin Nutr 1994;60:43-7.

26 De Vries JHM, Zock P, Mensick RP, Katan MB. Underestimation of energy intake by 3 day records compared with energy intake to maintain body weight in 269 nonobese adults. $\mathrm{Am} \mathrm{J}$ Clin Nutr 1994;60:855-60.

27 Bland JM, Altman DG. Statistical methods for assessing agreement between two methods of clinical measurement. Lancet 1986;1:307-10.

28 Bell SC, Bowerman AM, Nixon LE, Macdonald IA, Elborn JS, Shale DJ. Metabolic and inflammatory responses to pulmonary exacerbation in adults with cystic fibrosis. Eur $\mathrm{J}$ Clin Invest 2000;30(6):553-9.

29 Baarends EM, Schols AM, Westerterp KR, Wouters EF. Total daily energy expenditure relative to resting energy expenditure in clinically stable patients with COPD. Thorax 1997;52:780-5.

30 Baarends EM, Schols AMWF, Pannemans DLE, Westerterp KR, Wouters EFM. Total free living energy expenditure in patients with severe chronic obstructive pulmonary disease. Am J Respir Crit Care Med 1997;155:549-54.

31 Hugli O, Schutz Y, Fitting JW. The daily energy expenditure in stable chronic obstructive pulmonary disease. Am J Respir Crit Care Med 1996;153:294-300.

32 Mc Closkey M, Redmond AOB, Pyper S, Mc Cabe C, Westerterp KR, Elborn JS. Total energy expenditure in stable patients with cystic fibrosis. Clin Nutr 2001;85:166-71.

33 Bines JE, Truby HD, Armstrong DS, Phelan PD, Grimwood K. Energy metabolism in infants with cystic fibrosis. J Pediatr 2002;140:527-33.

34 Naon H, Hack S, Shelton MT. Resting energy expenditure evolution during antibiotic treatment for pulmonary exacerbation in Cystic Fibrosis. Chest 1993;103:1819-25.

35 Vic P, Ategbo S, Gottrand F, et al. Nutritional impact of antipseudomonas antibiotic courses in Cystic Fibrosis. Arch Dis Child 1997;76:437-40.

36 Reilly JJ, Ralston JM, Paton JY, et al. Energy balance during acute respiratory exacerbations in children with cystic fibrosis. Eur Respir J 1999;13:804-9.

37 Richards ML, Davies PS, Bell SC. Energy cost of physical activity in cystic fibrosis. Eur J Clin Nutr 2001;55:690-7.

Available online at www.sciencedirect.com

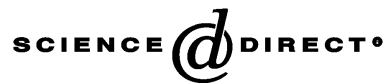

